\title{
CORRELATION BETWEEN LEVEL OF PERSONAL WELL-BEING AND SPIRITUALITY
}

\author{
TETIANA DANYLCHENKO \\ Department of Psychology, Academy of the State Penitentiary Service \\ Honcha str. 34, 14000 Chernihiv, Ukraine \\ E-mail address: dan20151975@gmail.com \\ ORCID: https://orcid.org/0000-0001-8809-0132
}

\begin{abstract}
Aim. The aim of this paper is to define the correlation between experiencing personal well-being and manifestations of spirituality of an individual.

Methods. The study involved the citizens of Chernihiv (average age -33.2 years old): 96 people in total, 40 men and 56 women. The following methods were used: a) to measure the components of personal well-being - Satisfaction with Life scale by E. Diener, Psychological well-being scale by C. Ryff, Questionnaire of parameters of subjective social well-being by T. Danylchenko; b) to measure the spiritual component - EPU Plus (Egoism - Personal Uniqueness) by L. Z. Levit, Methodology of measuring social interaction (mentality aspect) by G. L. Voronin.

Results and conclusion. The source of experiencing personal well-being is positive health (physical abilities, absence of physical limitations). Factors that decrease personal well-being are low level of tolerance and the pursuit of pleasure. Personal well-being is ensured by belief about collaboration and experiencing positive health as a state of readiness for activity. Psychological well-being has a negative correlation with basic egoism (the pursuit of pleasure) and a positive one with social egoism (ability to comply one's needs with the group interests, following social rules and norms). Subjective social well-being relates to the highest egoism (unique self-realization, realization of existing potential in an acceptable way). The orientation towards achieving personal or public goals determines the peculiarities of experiencing well-being in the eudaemonic and hedonistic dimensions.

Key words: personal well-being, spirituality, psychological well-being, subjective well-being, subjective social well-being
\end{abstract}

\section{INTRODUCTION}

$\mathrm{T}$ he concept of spirituality is extremely complex yet important. The list of quality of life parameters, defined by WHO, includes not only a person's physical health, psychological state, the level of independence and social relations, person's attitude to the environment, but also spirituality, religiosity and 
personal beliefs (WHOQOL Group, 1995, p. 1404). We do not aim to analyse the most widespread definitions of spirituality, as they are already discussed in the psychological literature (e.g., Emmons, 1999). The most generalised definition was made by R. Emmons, who defined spirituality as the sphere of life that "deals with the ultimate purpose and meaning of life, the set of principles and ethical beliefs that a person must follow, serving God or higher power, recognising the transcendent in everyday experience, the selfless focus and set of beliefs and practices created to establish relationships with the transcendent" (Emmons, 1999, p. 180).

We will assume that spirituality integrates aspects of the search for sense, ethical beliefs, transcendence and the apex of human capacity. In this paper we will consider not the religious variants of spirituality, but humanistic ones (as the highest personal truths).

The issue of correlation between spirituality and personal well-being lacks systematic research. There exist different views on the issue. Thus, spirituality is considered to be a component of personal well-being (B. Hettler, G. N. Masters, L. V. Kulikov), a factor of subjective well-being (E. Diener, M. Seligman, J. Helliwell, R. Putnam), an indicator of the level of well-being (B. S. Bratus, L. Z. Levit, A. V. Voronin).

Spirituality as a component of well-being. Some researches consider spiritual well-being to be a separate component of personal well-being (Masters, 2004; Hettler,1984). They define it as "faith in God, good fortune on one's life path, reconsidering life values and awareness of one's sense of life; belief in happiness and success on your life path" (Timofeeva, 2014, p. 267). Russian researcher Lev Kulikov also highlights the spiritual well-being; however, he interprets it as an opportunity to enjoy the riches of spiritual culture, awareness and experience of the sense of life, the presence of faith (Kulikov, 2000). Nina Borovskaya pinpoints spiritual well-being when identifying three components of general well-being: 1) spiritual and moral aspect: the sense of life and dignity of the person (the complex of virtues and their evaluation - awareness of one's own importance), mechanisms: intuition, conscience, responsibility; 2) the political and legal aspect: justice, firstly, as an awareness of one's own importance to others and the importance of others for oneself, and secondly, as a result of moral and political and legal control over the peaceful co-operation of individuals; 3 ) financial and economic aspect: satisfaction with material needs of life, money, institution of private property (Borovskaya, 2001).

Spirituality as a factor / criterion of well-being. Despite many discussions about the concept itself, the general conclusion of the researchers is that spirituality (its components) is one of the primary factors of an individual's wellbeing. Thus, according to Irina Dubrovina, psychological health should be considered in terms of the abundance of personal development, i.e. spiritual core, orientation towards the absolute values: Truth, Beauty, Good. Therefore, she proposes consideration of the ethical system as a criterion of psychological health (Dubrovina, 1997). 
Olga Masharskaya, who studied social perceptions of well-being, points to spiritual satisfaction as a criterion of well-being for Russian and Belarusian, but not for American students (Masharskaya, 2012).

In American social psychology, most of the research is focused on the study of subjective (hedonistic) well-being, which is measured by the level of realising one's own aspirations. Accordingly, it is acknowledged that these aspirations may conflict with social norms (for example, the most important desire of a person is to devote his life to gaining satisfaction, having fun without any worries or obligations). Hence, spirituality is seen as an "external" factor, which, on the contrary, may reduce hedonistic well-being, but increase psychological (eudaemonic) well-being. In addition, hedonistic search can hinder the person's spiritual development: misery itself is a means of spiritual development (Shamionov, 2004, p. 27).

Among the factors of subjective well-being are religion (Wilson, 1967; Finnis, Boyle, \& Grisez, 1987) or high levels of religiosity (Diener \& Seligman, 2004). Michael Argyle identifies religion and spirituality as factors of happiness. According to him, on one hand, religion makes it possible to find sense and purpose in life, and, on the other, it is one of the sources of social support (Argyle, 1987).

Overall, religiosity is a significant factor of enhancing the experience of subjective well-being: religious people report higher levels of subjective wellbeing than non-religious ones (Diener, Suh, Lucas, \& Smith, 1999). According to Andrew Clark and Orsolya Lelkes, religious faith is a buffer for stressors such as widowhood, unemployment and low income (Clark, \& Lelkes, 2003). The observance of religious practices is a stronger predictor than the presence of faith. John Helliwell and Robert Putnam explain this fact by saying that people who attend church more often interact positively with strangers, and consequently believe that other people can be trusted. Meanwhile, those who simply believe in God without realising their faith in social relations have no such belief (Helliwell \& Putnam, 2004). There are other explanations for this: faith gives life sense, meaning which is beyond personal (Argyle, 1987).

It has been pointed out that religious people are happier compared to nonreligious people, especially in religious communities. Church attendance has been found to have a greater impact on subjective well-being in the USA compared to Canada, but the observance of religious practices in the USA is twice as high as in Canada (Helliwell \& Putnam, 2004). Ed Diener suggested the notion of cultural congruence: people are happier (subjectively happy) if they have peculiarities that meet cultural standards (Diener, 2013).

The most detailed theory of spirituality was developed in the works of Robert Emmons. He viewed spiritual search as an attempt to establish what is sacred and worthy of reverence, and spirituality as a motivational desire (Emmons, 1999, p. 175). The necessity to distinguish between external (religion as a means of achieving goals) and internal (religion as a way of life) religiosity was emphasised. The author demonstrated that the first one has a negative correlation with well-being and the second one - positive. In his 
research, spiritual aspirations are associated with higher level of well-being (Emmons, 1999).

Spirituality as an indicator of the level of well-being. A worthy of attention level theory, which reconciles certain elements of personal well-being and the level of spiritual development, was proposed by Boris Bratus. In his opinion, it is possible to distinguish the egocentric level, when a person focuses primarily on achieving his/her own benefits and perceives the world and others only as a source of benefits. Accordingly, the criterion of well-being will be his hedonistic/emotional component. The group-centric level reflects the identification of a person with a small group ("one's own people"). The level of satisfaction of being in a close circle (family, friends) is measured by the scale of close relationships in the method of Carol Ryff and the Scale of subjective social wellbeing by Tatyana Danylchenko. The pro-social (humanistic) level relates to not only small but also large groups. There appears a recognition of universal values - trust in the world, healthy love for oneself, acceptance of the values of the other individuals. The spiritual, higher, level is the level at which "one defines personal relationship with the infinite, establishes his or her personal religion, i.e. the attitude to the ultimate questions and the sense of life" (Bratus, 1999, p. 293).

The theory of personality-oriented happiness by Leonid Levit is similar in psychological load. Although the author uses two dimensions: personal uniqueness and egoism, we will use the second one in our research. Leonid Levit believes that it has several levels. Biological egoism - positive health - body capabilities, the state of readiness for activity, the absence of physical limitations. Basic egoism is responsible for a "person's self-affirmation of his desire to realise his own interests and needs as quickly as possible without taking into account the thoughts and needs of others" (Levit, 2016, p. 17). The author also refers to it as hedonistic egoism associated with the process of getting pleasure. Reasonable egoism provides opportunities for social realisation, achievement of goals while taking into account other people's interests. L. Z. Levit does not differentiate the "close circle" and the community at large, designating them both as "groups". The highest level of egoism is reflected in a person's desire to devote his life to a unique self-realisation by limiting the basic (hedonistic) egoism and refocusing reasonable egoism on the higher values.

Among the representatives of the level approach is Anna Voronina, who defines spiritual activity, creative activity, productive activity, gaining insight into ethical, moral, philosophical achievements of culture as the parameters of the spiritual level of psychological well-being. The researcher claims that a person is at the highest level of self-realisation if he/she has: the social significance of his/her activity, his/her achievements; experience of highest "peak" feelings; absence of fear of death, end of existence, temporal changes; existential and functional fullness of individual existence (Voronina, 2002).

The correlation of levels in different theoretical concepts is presented in Table 1. 
Table 1

Correlation of levels of well-being and spirituality

\begin{tabular}{|c|c|c|c|c|}
\hline & A.V. Voronina & L.Z. Levit & B.S. Bratus & Methodologies \\
\hline $\begin{array}{l}\text { Subjective } \\
\text { (emotional) } \\
\text { well-being }\end{array}$ & $\begin{array}{l}\text { Biological level } \\
\text { (person as a } \\
\text { natural being) }\end{array}$ & $\begin{array}{l}\text { Biological } \\
\text { egoism } \\
\text { (survival) } \\
\text { Basic } \\
\text { egoism (self- } \\
\text { realisation) }\end{array}$ & $\begin{array}{l}\text { Egocentric } \\
\text { level }\end{array}$ & $\begin{array}{l}\text { Satisfaction } \\
\text { with Life scale } \\
\text { by E. Diener }\end{array}$ \\
\hline $\begin{array}{l}\text { Social well- } \\
\text { being in small } \\
\text { groups }\end{array}$ & $\begin{array}{l}\text { Social and } \\
\text { pedagogical } \\
\text { level (adopting } \\
\text { social norms } \\
\text { and standards) }\end{array}$ & $\begin{array}{l}\text { Reasonable } \\
\text { egoism }\end{array}$ & $\begin{array}{l}\text { Group-centric } \\
\text { level }\end{array}$ & $\begin{array}{l}\text { Questionnaire } \\
\text { of parameters } \\
\text { of subjective } \\
\text { social well- } \\
\text { being } \\
\text { Close } \\
\text { relationships } \\
\text { scale from } \\
\text { Psychological } \\
\text { well-being } \\
\text { scale by C. Ryff }\end{array}$ \\
\hline $\begin{array}{l}\text { Social well- } \\
\text { being in social } \\
\text { systems }\end{array}$ & $\begin{array}{l}\text { Social and } \\
\text { cultural level } \\
\text { (value and } \\
\text { meaning self- } \\
\text { realisation of a } \\
\text { person within } \\
\text { the adopted } \\
\text { cultural norms) }\end{array}$ & (altruism) & $\begin{array}{l}\text { Humanistic } \\
\text { level }\end{array}$ & $\begin{array}{l}\text { Social well- } \\
\text { being scale by } \\
\text { K. Keyes, } \\
\text { self- } \\
\text { transcendence } \\
\text { from the } \\
\text { Values } \\
\text { Questionnaire } \\
\text { by Schwartz }\end{array}$ \\
\hline $\begin{array}{l}\text { Psychological } \\
\text { (eudaemonic) } \\
\text { well-being }\end{array}$ & $\begin{array}{l}\text { Spiritual and } \\
\text { practical level } \\
\text { (humanistic } \\
\text { values, } \\
\text { perception of } \\
\text { truth) }\end{array}$ & $\begin{array}{l}\text { Highest egoism } \\
\text { (mature } \\
\text { individualism) }\end{array}$ & Spiritual level & $\begin{array}{l}\text { Personal } \\
\text { growth } \\
\text { scale from } \\
\text { Psychological } \\
\text { well-being } \\
\text { scale by C. Ryff }\end{array}$ \\
\hline
\end{tabular}

Source: own research.

The criteria of spirituality are extremely difficult to define empirically. The following criteria are mentioned: beliefs about engagement in society (Voronin, 2002), orientation towards ultimate values (Dubrovina, 1997; Yaremchuk, 2013), religiosity (Diener, Suh, Lucas, \& Smith, 1999; Helliwell \& Putnam, 2004), faith (Clark \& Lelkes, 2003), personal growth (Ryff \& Singer, 2008), comprehension of life in accordance with the limits (Emmons, 1999). Nathaniel Branden (2011) gives an unexpected point of view, as he considers egoism as the criterion of spirituality. He points out that true egoism is "a serious moral achievement because it involves the genuine concern of the 
individual for determining the sphere of personal interests, the responsibility for actions that lead to satisfaction, the uncompromising belief in one's own system of judgments, beliefs and values" (p. 76).

The study used the theoretical approach of considering personal well-being as "a specific combination of the properties of temperament, personality and positive personality traits that provide a person with the conditions to perform positive actions, have good interpersonal relationships, general positive attitude to himself and the world" (Baturyn, Bashkatov, \& Gafarova, 2012, p. 7). In American psychological literature, personal well-being is referred to as "prosperity." For example, Martin Seligman believes that prosperity is a positive psychological state that is characterised by positive emotions, involvement, positive relationships, significance and achievement of various positive results in work and life (Seligman, 2012). Basically, the components of hedonistic, eudaemonic and social well-being are enumerated. We consider personal well-being as a phenomenon which has the following components: emotional (hedonistic) well-being (in E. Diner's theoretical interpretation), psychological (eudaemonic) well-being (C. Ryff), social well-being (T. Danylchenko). In our study, we assumed that personal well-being is a systematic, heteroarchical complex of measurements that is not of a level nature. The theoretical model is shown in Figure 1.

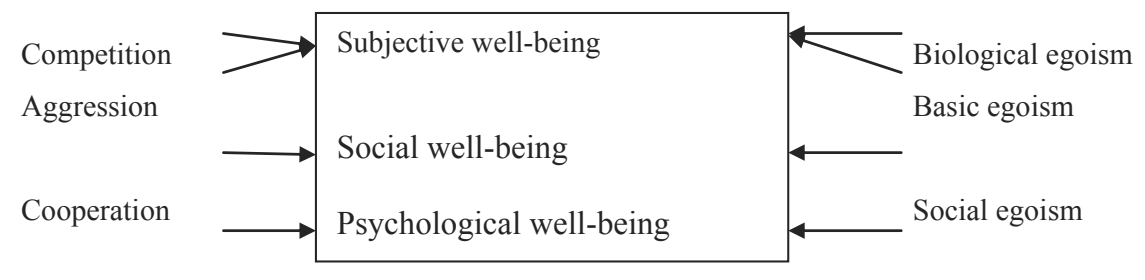

Tolerance

Highest egoism

Fig. 1.

Theoretical model of correlation between the level of personal well-being and spirituality

Source: own research.

The following methodologies were used in the study: to measure personal well-being - The Scale of Satisfaction with Life scale by Ed Diener adapted by Dmitriy Leontiev and Evgeniy Osin (2008), Psychological well-being scale by Carol Ryff adapted by Lidia Zhukovska and Evgeniya Troshykhina (2011), Questionnaire of parameters of subjective social well-being by T. Danylchenko; to measure spiritual component - EPU Plus (Egoism - Personal Uniqueness) by L. Z. Levit, Methodology of measuring social interaction (mentality aspect) by Gennadiy Voronin, which reveals moral beliefs about the ways of interaction in society. The study involved adult citizens of Chernihiv aged 21-55, average 
age -33.2 years old. The participants were the representatives of different professions. Total number of participants: 96 people - 40 men and 56 women. The mathematical and statistical processing of the results was carried out using the software packages SPSS Statistica 22.0 and AMOS 18.

Results Analysis. At the first stage, the factor structure of beliefs about interaction was clarified. According to G. L. Voronin, the leading spiritual determinants are cooperation - competition and tolerance - aggression. Combining these dimensions, four types can be defined: Ivan Karamazov (competition - tolerance), Alexey Karamazov (cooperation - tolerance), Dmitry Karamazov (cooperation - aggression), Fedir Karamazov (competition - aggression) (Voronin, 2002).

In the study, the mathematical and statistical analysis revealed 4 factors that explain $54.14 \%$ of the total variance. The first factor (contribution to the total variance $-20.44 \%$ ) combined such expressions as: "Love your neighbour as yourself" (factor load - .813), "Human for human is a friend, comrade and brother" (.738), "Better to live poor than to live with sin" (.582), "Woe to him who does no good to anyone" (.543), "Patience is the best salvation" (.436), which makes it possible to designate this factor as "Cooperation (altruism)."

The second factor (contribution - 14.88\%) included such expressions as: "If you live among wolves you have to act like one" (.757), "Every man lives for himself, and for others - when possible" (.600), "Barbarism is eradicated with barbaric methods" (.580), which gave reason to designate this factor as "Competition."

The third factor (contribution-10.27\%) is formed by thefollowing statements: "Eye for an eye, tooth for tooth" (.810), "One is not a thief unless caught stealing" (.708), "Love your neighbour, and hate your enemy" (.614), which allows us to designate this factor as "Aggression / Revenge."

The fourth factor (contribution - 8.55\%) included such descriptors as: "God endured and instructed us to do the same" (.689), "Ask and it will be given to you; seek and you will find; knock and the door will be opened to you" (.657), "Righteous work will not bring the chambers of stone" (.571),"Unless you deceive, you will not survive" (.539), "If someone slaps you on your right cheek, turn to him the other also" (.504), which makes it possible to designate this factor as "Tolerance / Asceticism."

K-means clustering was applied to group the respondents. Four groups (Table 2) were defined according to the beliefs about social interaction. 
Table 2

Distribution of beliefs about interaction by clusters*

\begin{tabular}{|c|c|c|c|c|}
\hline & $\begin{array}{c}\text { Cluster } 1 \\
17 \text { people }\end{array}$ & $\begin{array}{l}\text { Cluster } 2 \\
27 \text { people }\end{array}$ & $\begin{array}{l}\text { Cluster } 3 \\
24 \text { people }\end{array}$ & $\begin{array}{l}\text { Cluster } 4 \\
27 \text { people }\end{array}$ \\
\hline Love your neighbour as yourself & $3.82 \downarrow$ & $5.56 \uparrow$ & $5.54 \uparrow$ & $4.15 \downarrow$ \\
\hline $\begin{array}{l}\text { Human for human is a friend, } \\
\text { comrade and brother }\end{array}$ & $2.94 \downarrow$ & $5.74 \uparrow$ & $5.42 \uparrow$ & 4.48 \\
\hline $\begin{array}{l}\text { Better to live poor than to live } \\
\text { with sin }\end{array}$ & 3.71 & 4.70 & 4.79 & 3.52 \\
\hline $\begin{array}{l}\text { Woe to him who does no good to } \\
\text { anyone }\end{array}$ & 4.53 & 5.30 & 5.58 & 4.44 \\
\hline Patience is the best salvation & 3.35 & 4.78 & 3.92 & 4.14 \\
\hline Cooperation & $3.67 \downarrow$ & $5.05 \uparrow$ & $5.21 \uparrow$ & $4.15 \downarrow$ \\
\hline $\begin{array}{l}\text { If you live among wolves, you } \\
\text { have to act like one }\end{array}$ & 4.59 & 4.59 & $3.83 \downarrow$ & $5.22 \uparrow$ \\
\hline $\begin{array}{l}\text { Every man lives for himself, and } \\
\text { for others - when possible }\end{array}$ & $4.76 \uparrow$ & $4.74 \uparrow$ & $3.21 \downarrow$ & $4.85 \uparrow$ \\
\hline $\begin{array}{l}\text { Barbarism is eradicated with } \\
\text { barbaric methods }\end{array}$ & $4.65 \uparrow$ & 4.22 & $3.04 \downarrow$ & 3.59 \\
\hline Competition & $4.67 \uparrow$ & 4.52 & $3.36 \downarrow$ & $4.56 \uparrow$ \\
\hline Eye for an eye, tooth for tooth & $3.0 \downarrow$ & $5.11 \uparrow$ & $2.29 \downarrow$ & $4.22 \uparrow$ \\
\hline $\begin{array}{l}\text { One is not a } \\
\text { thief unless caught stealing }\end{array}$ & 2.65 & $4.30 \uparrow$ & $1.79 \downarrow$ & 3.52 \\
\hline $\begin{array}{l}\text { Love your neighbour, and hate } \\
\text { your enemy }\end{array}$ & $2.82 \downarrow$ & $4.56 \uparrow$ & $2.79 \downarrow$ & $4.26 \uparrow$ \\
\hline Agression & $2.82 \downarrow$ & $4.65 \uparrow$ & $2.29 \downarrow$ & $4.0 \uparrow$ \\
\hline $\begin{array}{l}\text { God endured and instructed us to } \\
\text { do the same }\end{array}$ & $4.94 \uparrow$ & $5.15 \uparrow$ & $3.17 \downarrow$ & $2.89 \downarrow$ \\
\hline $\begin{array}{l}\text { Ask and it will be given to you; } \\
\text { seek and you will find; knock and } \\
\text { the door will be opened to you }\end{array}$ & $3.88 \downarrow$ & $5.52 \uparrow$ & $5.92 \uparrow$ & $5.81 \uparrow$ \\
\hline $\begin{array}{l}\text { Righteous work will not bring the } \\
\text { chambers of stone }\end{array}$ & $5.18 \uparrow$ & $5.07 \uparrow$ & $3.58 \downarrow$ & 4.41 \\
\hline $\begin{array}{l}\text { Unless you deceive, you will not } \\
\text { survive }\end{array}$ & $3.88 \uparrow$ & $3.70 \uparrow$ & $2.08 \downarrow$ & 3.37 \\
\hline $\begin{array}{l}\text { If someone slaps you on your } \\
\text { right cheek, turn to him the other } \\
\text { also }\end{array}$ & 2.82 & $3.74 \uparrow$ & $2.50 \downarrow$ & $1.74 \downarrow$ \\
\hline Tolerance & $4.14 \uparrow$ & $4.58 \uparrow$ & $3.45 \downarrow$ & $3.64 \downarrow$ \\
\hline
\end{tabular}

At the next stage, k-means clustering of the general indicators of subjective, social and psychological well-being was applied. Three types of experiencing personal well-being were identified. The first cluster (34 people) included those respondents who had a high level of personal well-being (all indicators 
of well-being components were in the top third of the scale). The second cluster (43 people) included respondents with medium level of personal well-being and the third (18 people) with low level of personal well-being (Table 3).

Table 3

Distribution of respondents by personal well-being groups $(M)^{*}$

\begin{tabular}{|c|c|c|c|}
\hline & $\begin{array}{l}\text { High level of } \\
\text { well-being }\end{array}$ & $\begin{array}{l}\text { Medium level } \\
\text { of well-being }\end{array}$ & $\begin{array}{l}\text { Low level of } \\
\text { well-being }\end{array}$ \\
\hline Subjective (hedonistic) well-being & 25.68 & 19.37 & 15.11 \\
\hline $\begin{array}{l}\text { Psychological (eudaemonic) well- } \\
\text { being }\end{array}$ & 202.65 & 182.72 & 158.06 \\
\hline Subjective social well-being & 129.62 & 109.19 & 71.67 \\
\hline
\end{tabular}

Note: * level of statistical significance of the differences between all indicators $\mathrm{p} \leq .01$

Source: own research.

As we were interested in the peculiarities of ethical beliefs about interacting with others, a frequency analysis of the dominant interaction strategies in each group was performed (Table 4).

Table 4

Distribution of ethical strategies in groups with different levels of personal well-being $(\%)$

\begin{tabular}{l|c|c|c}
\hline \multicolumn{1}{c}{ Strategies } & $\begin{array}{c}\text { High level of } \\
\text { well-being }\end{array}$ & \multicolumn{1}{c}{$\begin{array}{c}\text { Medium level of } \\
\text { well-being }\end{array}$} & $\begin{array}{c}\text { Low level of } \\
\text { well-being }\end{array}$ \\
\hline Competition - Tolerance & 5.9 & 20.9 & 35.3 \\
Cooperation - Aggression & 29.4 & 25.6 & 35.3 \\
Cooperation & 35.3 & 25.6 & 5.9 \\
Competition - Aggression & 29.4 & 27.9 & 23.5 \\
\hline & $100 \%$ & $100 \%$ & $100 \%$ \\
\hline
\end{tabular}

Source: own research.

Low level of well-being is more common for our respondents who are oriented towards competitive types of relationships. In all the selected groups, there was almost no difference in level of beliefs about cooperation (average 4.46 to 4.69 points), aggression ( 3.46 to 3.76 points) and tolerance (3.78 to 4.09 points), whereas the beliefs about competition is more variable. Thus, people with a low level of personal well-being are more likely to have beliefs about competition (4.65 points), when people with a high level of personal well-being are less likely to agree with such a strategy (3.87 points). However, the differences are not statistically significant. People with medium level of well-being have no preference for a particular strategy. Obviously, this is not about the level of expression of the cognitive component, but about how often one chooses a certain strategy for interacting with the world and other people. In the current sociocultural context, those people who are oriented towards cooperation at the level of social perceptions have certain advantages. 
In the group with low level of well-being, two strategies are preferred: 1) orientation towards achieving goals at any cost (ignoring both one's own needs and needs of close people); 2) orientation towards helping with the conviction that there are no irreplaceable people. As we see, individuals with low level of personal well-being have immature internally conflicting beliefs about social interaction, and therefore they do not receive adequate social support.

Respondents with high level of personal well-being are focused on perseverance in combination with personal responsibility for themselves and their social environment (G. L. Voronin points out that this strategy is more often chosen by older people with extensive life experience). In the group with medium level of personal well-being, all identified strategies are represented equally, with a slight advantage of orientation towards confrontation and urgency in achieving the goal.

Table 5

Distribution of egoism indicators (using EPU method) in groups with different levels of personal well-being*

\begin{tabular}{l|c|c|c}
\hline \multicolumn{2}{c}{$\begin{array}{c}\text { High level of well- } \\
\text { being }\end{array}$} & $\begin{array}{c}\text { Medium level of } \\
\text { well-being }\end{array}$ & $\begin{array}{c}\text { Low level of well- } \\
\text { being }\end{array}$ \\
\hline Biological level & $10.03 \uparrow$ & $9.35 \uparrow$ & $7.33 \downarrow$ \\
Basic & 6.79 & 7.65 & 7.72 \\
Social & 15.03 & 14.42 & 13.28 \\
Highest & $25.36 \uparrow$ & $24.44 \uparrow$ & $19.0 \downarrow$ \\
\hline
\end{tabular}

Note: ${ }^{*} \downarrow$ - groups that are different from the others at a statistically significant level $(\mathrm{p} \leq .01)$

Source: own research.

To study the effect of spirituality on the parameters of personal well-being, a linear regression analysis was performed, in which the dependent variable was alternately indices of personal well-being, and independent variable levels of egoism and ethical beliefs. Thus, in the process of stepwise multiple regression $\left(\mathrm{R}^{2}=.404\right)$, the biological level of egoism turned out to be the most important variable in the equation and explained approximately $8.3 \%$ of the variance of subjective well-being $(\beta=.250, p \leq .05 ; \beta$ - standardised regression coefficient). These results are expected, as positive health as a state of readiness for activity is the basis for experiencing positive affect. Ethical belief about cooperation was the second variable and explained the additional $4.3 \%(\beta=$ $.220, \mathrm{p} \leq .05)$. Highest (mature) egoism was the third variable $(\beta=.196, \mathrm{p} \leq .05)$ and accounted for $3.7 \%$.

When constructing a regressive model of psychological well-being $\left(\mathrm{R}^{2}=.703\right)$, biological egoism was the most important variable, which explained $24.1 \%$ of the variance $(\beta=.400, p \leq .001)$. Highest (mature) egoism was the second most significant variable $(16.4 \%$ of the variance, $\beta=.389, \mathrm{p} \leq$ $.001)$. The third variable was social egoism ( $4 \%$ of variance, $\beta=.236, \mathrm{p} \leq .01)$, and in the last place, basic egoism $(5 \%$ of variance, $\beta=-.227, p \leq .01)$. At the 
same time, it should be mentioned that basic egoism negatively affects experiencing psychological well-being. In the concept of L. Z. Levit, basic egoism is about the pursuit of pleasure. In this context, the existence of a hedonistic paradox has been empirically confirmed: subject's greater concentration on experiencing own satisfaction leads to the disappearance of pleasant feelings (Yalom, 1999). One of the works of American psychologists shows that meeting basic needs is associated with negative affect (Tay, Diener, 2011). Individuals with high level of basic egoism were proven to have low level of well-being by other studies as well (Helliwell, 2011). Interestingly, it has been found that social egoism affects not social well-being (as expected), but the psychological component of personal well-being. Social egoism is interpreted as the ability to reconcile one's needs with the interests of the group, adherence to social rules and norms, the ability to organise contacts in the individual's area of interest. Studies have confirmed that people who follow social norms have a higher level of subjective well-being (Fulmer et al., 2011).

When examining the effect of particular aspects of spirituality on experiencing subjective social well-being, the following data were obtained $\left(R^{2}=.503\right)$. In the first place - biological egoism ( $16.1 \%$ of the variance, $\beta=.361, \mathrm{p} \leq .001$ ), in the second place - highest egoism (5.9\% of the variance, $\beta=.271, \mathrm{p} \leq .01$ ), in the last place - basic egoism ( $3.3 \%$ of the variance, $\beta=-.183, p \leq .05)$. Highest egoism is seen as a unique self-realisation, the realisation of existing potential in an ethically acceptable way. It should be noted that in his work L. Z. Levit points out typically negative attitude toward a person with high abilities (due to disadvantageous contrast). The loneliness of extremely gifted people was described in literature (Zinoviev, 2005). However, in our study, mature egoism has become a factor of subjective and social well-being, showing a shift in values towards social recognition.

Thus, the absence of physical limitations, physical opportunities are a common factor of personal well-being. Basic egoism has a negative effect on experiencing well-being. Social egoism influences the psychological (eudaemonic) component of personal well-being.

These results are consistent with the conclusions made by A. Waterman, who found that people with high levels of individualism are less likely to experience negative affects, and their behaviour shows fewer social deviations. They are more tolerant and eager to cooperate (Waterman, 1984).

The basic model of the correlation between the aspects of spirituality and the dimensions of personal well-being is presented in model 1. Structural modelling was carried out by using software AMOS 18. The model has the following suitability parameters: $\mathrm{CMIN}=33.59, \mathrm{p}=.448 \geq .01 ; \mathrm{X}^{2} / \mathrm{df}=.998 \leq 2$; RMSEA = .002 $\leq .05 ;$ LO90 = .000 $\leq .1 ;$ HI90 = .074 $\leq .1$; PCLOSE $=.792 \geq .5$; $\mathrm{GFI}=.938 \geq .9, \mathrm{CFI}=1.0 \geq .95, \mathrm{R}^{2}=.618$. 


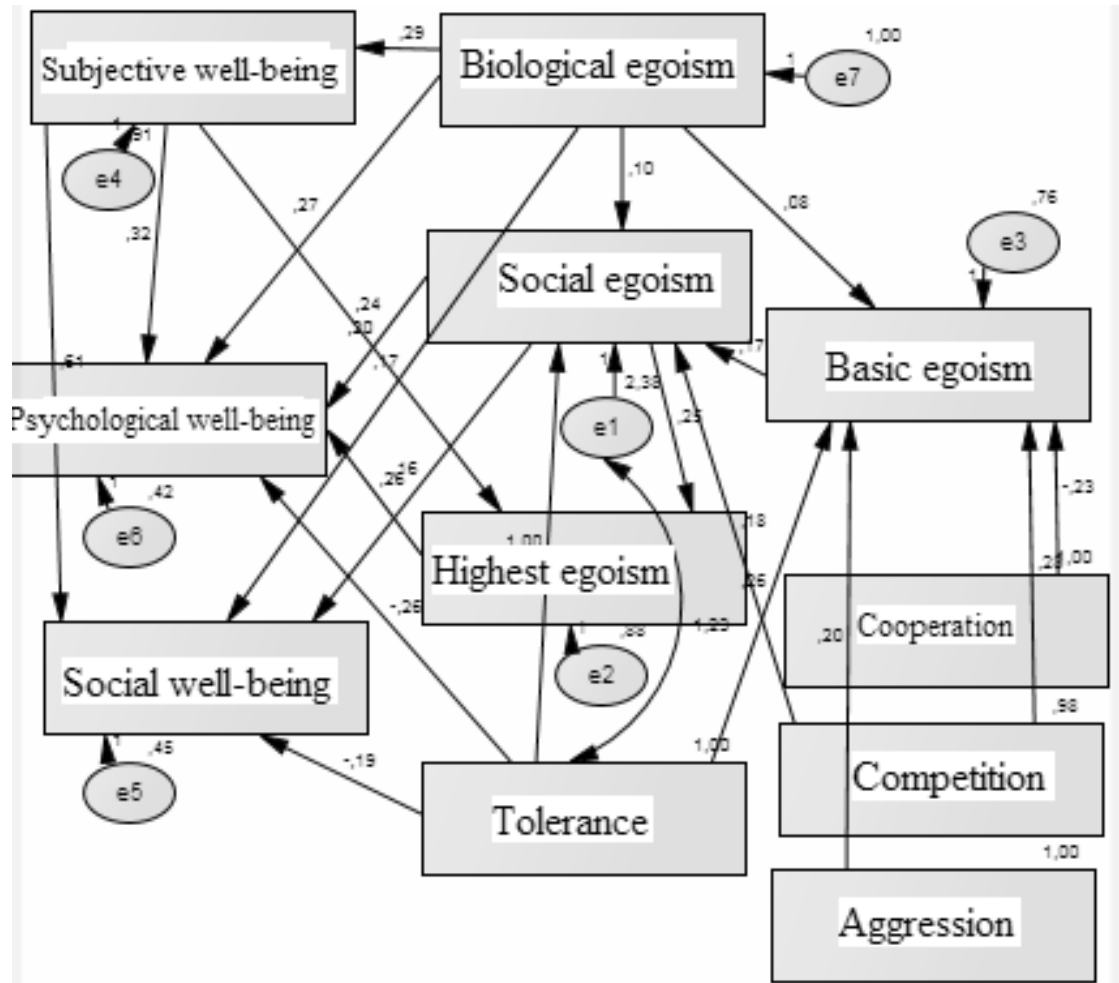

Fig. 2.

Empirical model of the correlation between the level of personal well-being and spirituality

Source: own research.

As we can see from the graphical model, the original hypothesis has not been confirmed. Ethical beliefs about interacting with the world and people affect experiencing personal well-being not directly, but through the personal concept of well-being. That is, ethical beliefs determine the style of life self-realisation and orientation toward personal or social goals. Further, the personal style determines the peculiarities of experiencing well-being in the eudaemonic and hedonistic dimension.

\section{CONCLUSIONS}

The following conclusions can be drawn. Firstly, ethical beliefs about interaction with the world and people, orientation towards achieving personal or social goals is an aspect of the personal concept of well-being.

In the group with low level of well-being, people prefer orientation towards pursuing goals at any cost and orientation towards being helped by other 
people. Respondents with a high level of personal well-being are oriented towards perseverance, combined with personal responsibility for themselves and their social environment. In the group with medium level of personal well-being, all identified strategies are equally represented.

Secondly, some aspects of personal well-being are related to different aspects of an individual's spirituality. Subjective (affective) well-being is ensured by the belief about cooperation and experiencing positive health as a state of readiness for activity. Psychological (eudaemonic) well-being is negatively connected with basic egoism (pursuit of pleasure) and positively with social egoism (the ability to reconcile one's needs with the interests of the group, adherence to social rules and norms). Subjective social well-being is associated with highest egoism (unique self-realisation, realisation of the available potential in an ethically acceptable way). Orientation towards achieving personal or social goals determines the peculiarities of experiencing well-being in the eudaemonic and hedonic dimensions.

Thirdly, positive personal health (physical ability, lack of physical limitations) is the source of personal well-being. Factors that reduce personal well-being are low tolerance and high levels of basic egoism.

In our opinion, further research is needed to study the personal concept of well-being in the light of cultural specificity.

\section{REFERENCES}

[1] Argyle, M. (1987). The psychology of happiness. London: Routledge.

[2] Baturyn, N. A., Bashkatov, S. A., \& Gafarova, N. V. (2012). Теоретическая модель личностного благополучия [Theoretical model of personality well-being]. Vestnyk JuUrGU, Sery ya «Psy`xology ya», 6(4), 4-14.

[3] Borovskaya, N. V. (2001). Благополучие как социокультурный феномен: Авт-т канд. филос. наук. [Well-being as a sociocultural phenomenon]. $\mathrm{PhD}$ thesis. Tyumen.

[4] Branden, N. (2011). Разве не все мы эгоисты? [Aren't we all selfish?]. In: Rand, A. Dobrodetel' egoizma (pp. 71-76). Moskva: Альпина Паблишерз.

[5] Bratus, B. S. (1999). Личностные смыслы по А.Н. Леонтьеву и проблема вертикали сознания [Personal meanings according to A.N. Leont'ev and the problem of the vertical of consciousness]. In: Voyskunskiy, A., Zhdan, A., \& Tikhomirova, O. (Eds.). Traditsii i perspektivy deyatel'nostnogo podkhoda v psikhologii: shkola A.N. Leont'yeva (pp. 285-298). Moskva: Смысл.

[6] Clark, A. E., \& Lelkes, O. (2003). Keep the faith: Is social capital just an instrument? Unpublished manuscript, De.partment et Laboratoire d'Economic Theoretique et Applique.e, Paris, France.

[7] Diener, E., \& Seligman, M. (2004). Beyond money: Toward an economy of well-being. Psychological Science in the Public Interest, 5, 1-31.

[8] Diener, E., Suh, E., Lucas, R., \& Smith, H. (1999). Subjective well-being: Three decades of progress. Psychological Bulletin, 125, 276-302.

[9] Dubrovina, I. V. (1997). Психологические аспекты психического здоровья детей и школьников [Psychological aspects of the mental health of children and schoolchildren]. In Dubrovina, I. V. (Ed.). Rukovodstvo prakticheskogo psikhologa: psikhologicheskoye zdorov'ye detey $i$ podrostkov v psikhologicheskoy sluzhbe (pp. 7-19). Moskva: Академия.

[10] Emmons, R. (1999). The Psychology of Ultimate Concerns. Motivation and Spirituality in Personality. N. Y., London: The Guilford Press.

[11] Finnis, J., Boyle, J. M., \& Grisez, G. (1987). Nuclear deterrence, morality and realism. Oxford: Clarendon Press. 
[12] Fulmer, C. A., Gelfand, M. J., Higgings, E. T. et al. (2011). On «Feeling Right» in Cultural Contexts: How Person-Culture Match Affects Self-Esteem and Subjective. Psychological Science, 21, 1563-1569.

[13] Helliwell, J. F. (2011). Felicitators. International Journal of Wellbeing, 1(2), 193-306.

[14] Helliwell, J. F., \& Putnam, R. D. (2004). The social context of well-being. Philosophical transactions-royal society of London, series B biological sciences, 359, 1435-1446.

[15] Hettler, B. (1984). Wellness: Encouraging a life time pursuit of excellence. Health values, 8(4), 13-17.

[16] Kulikov, L. V. (2000). Детерминанты удовлетворенностью жизнью [Determinants of life satisfaction]. In: Bolshakov, V. (Ed.). Obshchestvo i politika. Sovremennyye issledovaniya, poisk kontseptsiy (pp. 476-510). St. Petersburg: Изд-во С.-Петербургского ун-та.

[17] Levit, L. Z. (2016). Психологія розвитку й реалізації життевого потенціалу суб'єкта: Авт-т докт. псих. наук [The psychology of development and realization of a subject's life potential]. PsD thesis. Kyiv.

[18] Masharskaya, O. S. (2012). Кросскультурные различия социальных представлений студентов о благополучии: Авт-т канд. псих. наук [Cross-cultural differences in students' social perceptions of well-being]. PhD thesis. Kursk.

[19] Masters, G. N. (2004). Conceptualising and Researching Student Wellbeing. Retrieved May 12, 2015, from http://research.acer.edu.au/cgi/viewcontent.cgi?article=1001\&context =research_conference_2004

[20] Panina, E. N. (2006). Взаимосвязь суверенности психологического пространства и субъективного благополучия личности: Ав-т канд. псих. наук [The relationship of the sovereignty of the psychological space and the subjective well-being of the individual]. $\mathrm{PhD}$ thesis. Krasnoyarsk.

[21] Ryff, C. D., \& Singer, B. (2008). Know thyself and become what you are: A eudaimonic approach to psychological well-being. Journal of Happiness Studies, 9(1), 13-39.

[22] Seligman, M. E. P. (2012). Flourish. A Visionary New Understanding of Happiness and Well-being. N.Y.: Atria Books.

[23] Shamionov, R. M. (2008). Субъективное благополучие личности: психологическая картина и факторы [Subjective well-being of a person: psychological picture and factors]. Saratov: Научная книга.

[24] Tay, L., \& Diener, E. (2011). Needs and Subjective Well-Being Around the World. Journal of Personality and Social Psychology, 101(2), 354-365.

[25] Timofeeva, Y. I. (2014). Субъективное благополучие личности в обществе [Subjective well-being of an individual in society]. In: Barysheva, G., \& Borisova, L. (Eds.). Obshchestvo $i$ nepreryvnoye blagopoluchiye cheloveka (pp. 265-269). Tomsk: Изд-во ТПУ.

[26] Voronin, G. L. (2002). К вопросу о конструировании социологического теста (измерение ментальности) [To the question of constructing a sociological test (measuring mentality)]. Sotsiologiya, 15, 93-109.

[27] Voronina, A. V. (2002). Оченка психологического благополучия школьников в системе профилактической и коррекционной работы психологической службы: Авт-т канд. псих. наук [Assessment of the psychological well-being of schoolchildren in the system of preventive and correctional work of the psychological service]. PhD thesis. Tomsk.

[28] Waterman, A. S. (1984). The Psychology of Individualism. New York: Praeger

[29] WHOQOL Group. (1995). The World Health Organization Quality of Life Assessment (WHOQOL): Position paper from the World Health Organization. Social Science and Medicine, 41(10), 1403-1409.

[30] Wilson, W. (1967). Correlations of avowed happiness. Psychological Bulletin, 67, 294-306.

[31] Yalom, I. (1999). Экзистенциальная психотерапия [Existential psychotherapy]. Moskva: Класс.

[32] Yaremchuk, S. V. (2013). Субъективное благополучие как компонент ценностносмысловой сферы личности [Subjective well-being as a component of the value-semantic sphere of personality]. Psikhologicheskiy zhurnal, 5, 85-95.

[33] Zinoviev, А. А. (2005). Исповедь отщепенияа [Confession of a renegade]. Moskva: Вагриус. 